\title{
FROM SINK TO RESURGENCE: THE BUFFERING CAPACITY OF A CAVE SYSTEM IN THE TONGASS NATIONAL FOREST, USA
}

\author{
OD PONORA DO IZVIRA: PUFRSKA KAPACITETA JAMSKIH \\ SISTEMOV V NARODNEM GOZDU TONGASS, ZDA
}

\author{
Melissa R. HENDRICKSON ${ }^{1}$ \& Chris GROVES $^{2}$
}

\begin{abstract}
UDC 551.444(739.8)

Melissa R. Hendrickson \& Chris Groves: From sink to resurgence: the buffering capacity of a cave system in the Tongass national forest, USA

The Tongass National Forest of Southeast Alaska, USA, provides a unique environment for monitoring the impact of the cave system on water quality and biological productivity. The accretionary terrane setting of the area has developed into a complex and heterogeneous geologic landscape which includes numerous blocks of limestone with intense karstification. During the Wisconsian glaciation, there were areas of compacted glacial sediments and silts deposited over the bedrock. Muskeg peatlands developed over these poorly drained areas. The dominant plants of the muskeg ecosystem are Sphagnum mosses, whose decomposition leads to highly acidic waters with $\mathrm{pH}$ as low as 2.4. These waters drain off the muskegs into the cave systems, eventually running to the ocean. In accordance with the Tongass Land Management Plan, one of the research priorities of the National Forest is to determine the contributions of karst groundwater systems to productivity of aquatic communities. On Northern Prince of Wales Island, the Conk Canyon Cave insurgence and the Mop Spring resurgence were continuously monitored to understand the buffering capacity of the cave system. Over the length of the system, the $\mathrm{pH}$ increases from an average 3.89 to 7.22 . The insurgence water temperature, during the summer months, ranged from between $10^{\circ} \mathrm{C}$ to $17^{\circ} \mathrm{C}$. Af ter residence in the cave system, the resurgence water had been buffered to $6^{\circ} \mathrm{C}$ to $9^{\circ} \mathrm{C}$. Over the continuum from insurgence to resurgence, the specific conductance had increased by an order of magnitude with the resurgence waters having a higher ionic strength. The cave environment acts as a buffer on the incoming acidic muskeg water to yield resurgence water chemistry of a buffered karst system. These buffered waters contribute to the
\end{abstract}

Izvleček UDK 551.444(739.8)
Melissa R. Hendrickson \& Chris Groves: Od ponora do izvira:
Pufrska kapaciteta jamskih sistemov v Narodnem gozdu Ton-
gass, ZDA
Narodni gozd Tongass, na jugovzhodni Aljaski, ZDA, je izjemo okolje za spremljanje vpliva jamskega sistema na kvaliteto vode in $z$ njo povezano biološko produkcijo. Geološko pestro območje vključuje številna območja apnenca $z$ intenzivnim zakrasevanjem. Med zadnjo ledeno dobo so se na karbonatno podlago ponekod odložili ledeniški sedimenti in melji. Tu so se zaradi slabega odvodnjavanja razvila barja (muskegi), na katerih prevladuje šotni mah. Zaradi razpada šotnih mahov iz barij v kras odtekajo zelo kisle vode, $\mathrm{z}$ minimalnim $\mathrm{pH}$ 2,4. Prostorsko ureditveni načrt območja Tongass med prioritetne naloge uvršča tudi določitev pomena kraških vodonosnikov $\mathrm{v}$ produktivnosti vodnih združb. $\mathrm{Z}$ namenom določitve pufrske kapacitete kraških sistemov smo zvezno na severnem delu otoka Walškega princa opazovali parametre na ponoru $\mathrm{v}$ jami Cong Canyon in izviru Mop. Med opazovanima točkama $\mathrm{pH} v$ povprečju naraste iz 3,89 na 7,22 . Temperatura ponorne vode je v poletnih mesecih med $10^{\circ} \mathrm{C}$ in $17^{\circ} \mathrm{C}$, voda na izviru pa med $6^{\circ} \mathrm{C}$ in $9^{\circ} \mathrm{C}$. Med ponorom in izvirom specifična električna prevodnost naraste skoraj za red velikosti. Jamsko okolje deluje za kot pufer za kisle vode, ki dotekajo z barij. Vode, ki se precejajo skozi kras, zato pomembno vplivajo na dolvodno produkcijo vodnih združb. Vode iz opazovanega sistema se stekajo $\mathrm{v}$ Whale Pass, ki predstavlja pomembno mesto v industriji lososa. Naša opazovanja so potrdila, da pufrski učinek kraškega sistema zagotavlja kemično in temperaturno ugodno vodo in $\mathrm{s}$ tem pomembno vpliva na produktivnost mladih lososov vrste Oncorhynchus kisutch (angl. coho salmon).

Ključne besede: kras, pufrska kapaciteta, barje (muskeg), Narodni gozd Tongass, Aljaska.

\footnotetext{
${ }^{1}$ Ashley National Forest, Vernal, Utah, e-mail: melissarhendrickson@gmail.com

${ }^{2}$ Western Kentucky University, Bowling Green, Kentucky, e-mail: chris.groves@wku.edu

Received/Prejeto: 4.3.2010
} 
productivity in aquatic environments downstream. The waters from this system drain into Whale Pass, an important location for the salmon industry. The cool, even temperatures, as well as buffered flow rates delivered by the karst systems are associated with higher productivity of juvenile coho salmon.

Keywords: karst, buffering, muskeg, Tongass National Forest, Alaska.

\section{INTRODUCTION: THE KARST ENVIRONMENT OF SOUTHEAST ALASKA}

The Tongass National Forest is comprised of 6.9 million hectares of coastal temperate rainforest. The geologic history of the area led to the development of the highly fractured and fragmented Alexander Terrane that makes up the pan handle of Alaska. Blocks of limestone are numerous and have undergone intense karstification. Tills deposited during the Wisconsin (Marine Isotope Stage 2) glacial episode created areas of impermeable clays and silts perched over carbonate bedrock. Muskeg peat bogs, composed of upper layers of living sphagnum moss and lower layers of partially decomposed sphagnum moss, developed on these poorly drained glacial deposits. The combination of these layers makes up the fibrous brown peat which characterizes a muskeg. Decomposition of dead plants is inhibited by the absence of oxygen; therefore the muskegs are rich in humic substances. The presence of these humic substances result in peatlands, typically having highly acidic water with $\mathrm{pH}$ ranging from 2.4 to 5.8 (Elliot 1994).
In some locations, the highly acidic waters from these muskegs run onto the carbonate strata and enter the groundwater system through developed cave systems. These waters later resurge downstream as buffered karst streams which play an important role in the fishing industry. It has been suggested that karst dominated aquatic systems support higher biodiversity than nonkarst areas because of the high calcium concentrations and may even have higher growth rates for some species (Swanston 1993). One research priority of the National Forest, as stated in the Tongass Land Management Plan, is to determine the contributions of the karst groundwater systems to the productivity of the aquatic communities. The first step in investigating this relationship is to understand the changes in water chemistry that occur from acidic insurgence to buffered resurgence.

\section{STUDY AREA}

The study area is located in the Tongass National Forest, Northern Prince of Wales Island, Alaska in the Conk Canyon - Mop Spring drainage system (Fig. 1). Dye tracing has shown that water draining off the peatlands flows into the karst of Conk Canyon, which resurges at Mop Spring and eventually flows out Whale Pass (Prussian \& Baichtal 2003). While the Conk Canyon muskeg is not the only input to the system, it is assumed for this study that it is representative of the multiple muskeg drain- ages that also resurge at Mop Spring. Conk Canyon is a single muskeg catchment area of around 2 hectares (GIS approximation); whereas Mop Spring has inputs from multiple sources over a 200 hectare watershed. While this may be a small fraction of the spring flow, other allogenic inputs in the area coming off the muskeg have similar chemistry signatures. Due to the geology of the area with the glacial hardpan overlying the karst, most of the water in the system occurs as allogenic recharge. 


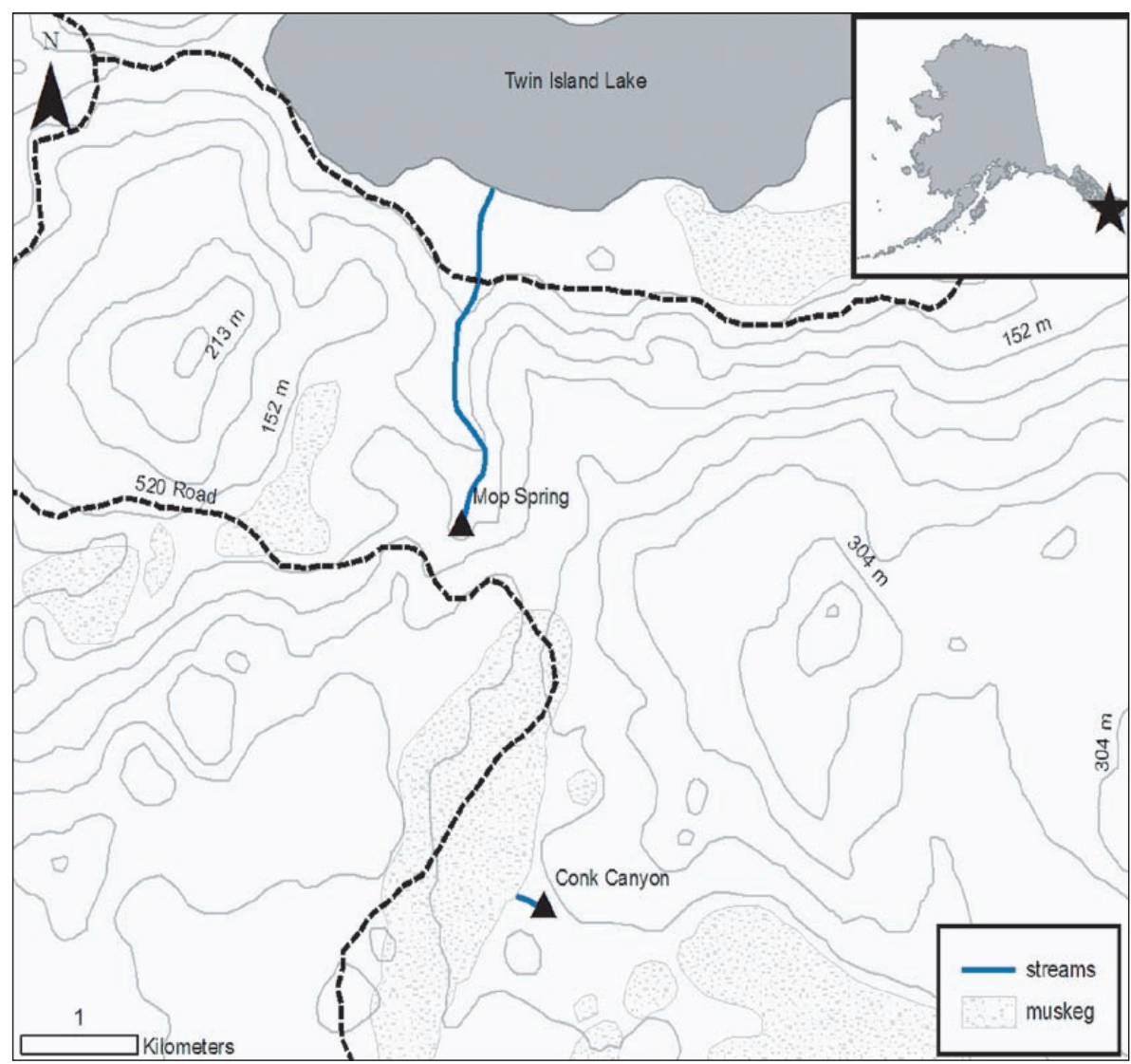

Fig. 1: Study location with acidic insurgence of Conk Canyon and the karst Mop Spring. Twin Island Lake then flows to Whale Pass.

\section{STUDY METHODS}

Continuous data measurements of $\mathrm{pH}$, temperature, stage, and specific conductance were taken in the waters of the Conk Canyon muskeg and the Mop Spring resurgence. A Campbell Scientific CR10X datalogger was used with a two minute resolution to capture the changing natural conditions. The $\mathrm{pH}$ was measured with Cole-Parmer double-junction industrial in-line ATC $\mathrm{pH}$ sensors connected to a 3 meter shielded coaxial cable which terminated in the instrument box at a Cole-Parmer preamplifier to increase signal stability. Measurements of $\mathrm{pH}$ were recorded in millivolts and had an accuracy of $+/-0.01$ SU. The values the probes recorded were assumed to drift over the course of the study. To correct for this drift, they were calibrated with three $\mathrm{pH}$ standards, 4.01, 7.00, and 10.00 to create a regression and line equation to obtain the $\mathrm{pH}$ values. CSI CS547A-L specific conductance/temperature sensors were used with accuracy of $+/-0.1^{\circ} \mathrm{C}$ and +/- $0.001 \mathrm{mS}$. Stage was measured by Campbell Scientific Druck PDCR 1830-8388 submersible pressure transducers with an accuracy of $+/-0.1 \%$ FSO. The dataloggers were installed on Julian Day 166 of 2006 (June 15) and taken offline on Julian Day 236 (August 24) giving a data collection period of 70 days. The rainfall data was collected once daily at a gauge located in the area. The continuous temperature data was obtained from the weather monitoring station in Thorne Bay, Alaska. 


\section{RESULTS AND DISCUSSION}

The continuous data was collected and analyzed to determine the evolution of the water from insurgence to resurgence. One buffering effect of the cave system is on the temperature of the water. The muskeg waters of the Conk Canyon insurgence are open to the atmosphere,

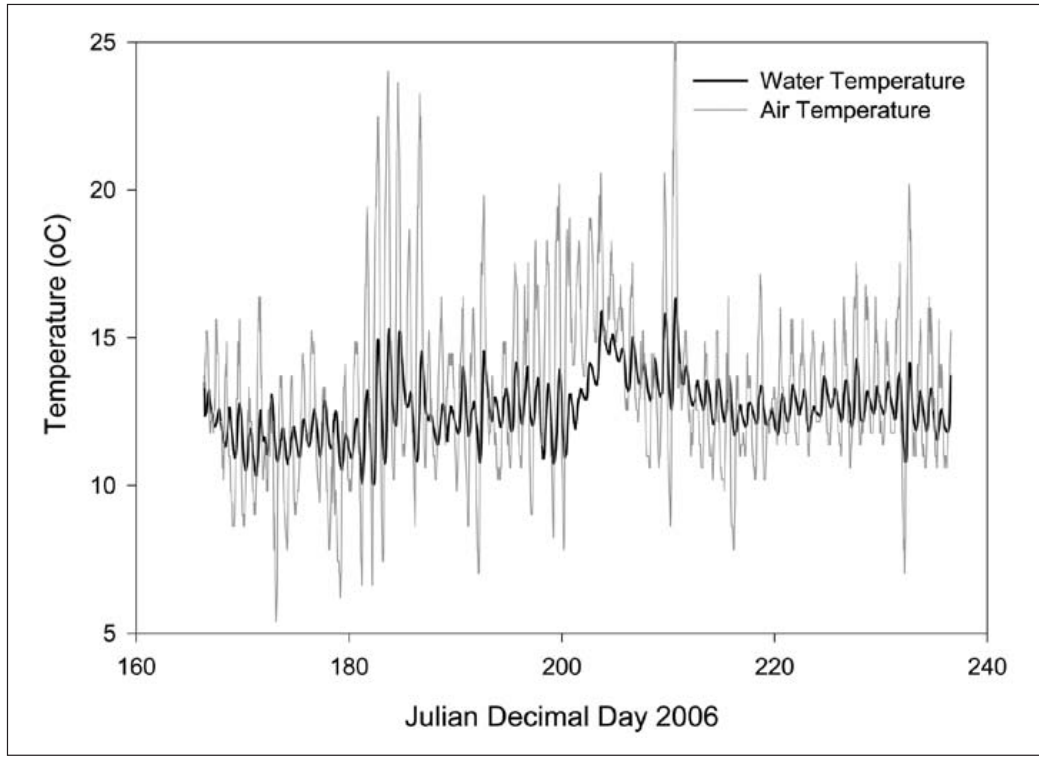

Fig. 2: Water temperature at the Conk Canyon muskeg and air temperature.

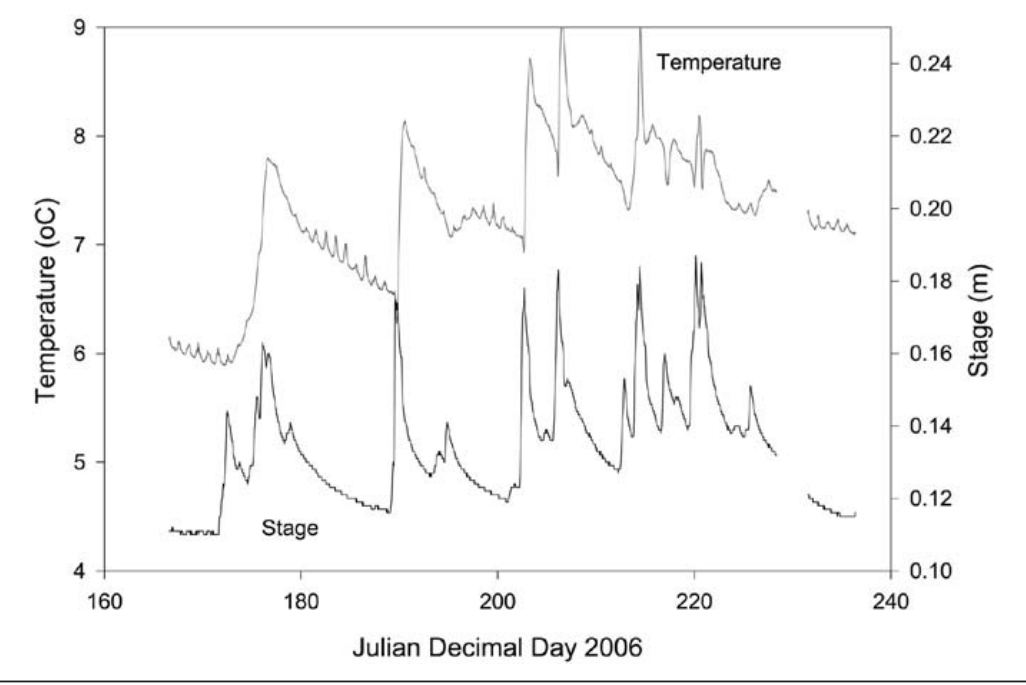

Fig. 3: Water temperature and stage height for the Mop Spring datalogger site.

and thus the water temperature reflects the average daily air temperature for the study period (Fig. 2). The larger fluctuations in air temperature, as seen around Julian
Day 180 are during good weather. Because of the clear skies, the temperatures tend to be higher during the day and lower at night because there is no cloud cover to keep the heat overnight. When there was cloudy weather, the night and day temperature differences were less. The temperature range for the insurgence waters was between $10^{\circ} \mathrm{C}$ to $17^{\circ} \mathrm{C}$.

The water temperature exiting the cave system at Mop Spring showed a greater correlation on the stage height of the water coming out of the system (Fig. 3). After residence in the cave system, the resurgence water had been buffered to $6^{\circ} \mathrm{C}$ to $9^{\circ} \mathrm{C}$. During the beginning of the study, the water coming out of the karst system was a little above $6^{\circ} \mathrm{C}$. From June $5^{\text {th }}, 2006$ to June $22^{\text {nd }}, 2006$ there were no large precipitation events. From the $22^{\text {nd }}$ onwards, when there was an increase in stage from precipitation, there was an increase in the water temperature resurging at Mop Spring. This increase reflects the input of water into the system that hasn't had time to reach equilibrium with the groundwater temperature. After the first rain event, the relaxation time was never long enough before the next storm for the water temperature to return to equilibrium with the groundwater temperature. Over the course of the study period, there is a increasing trend in the resurgence water temperature. This increase in temperature is both from the increase in water coming through the system that hasn't had time to equilibrate as well as the increase in the water temperature from the input system (seen in Fig. 2) over the study period.

The most apparent change in water chemistry from the insurgence to the resurgence is the increase in $\mathrm{pH}$ (Fig. 4). The $\mathrm{pH}$ averaged 3.89 in the acidic waters of the muskeg at Conk Canyon. It ranged from a low of 3.60 to a high of 4.27 over the study period. The lowest $\mathrm{pH}$ values were recorded at the beginning of storm events when the stage increased. During the increased rainfall, there is more water traveling through the muskeg and draining into the karst. The 


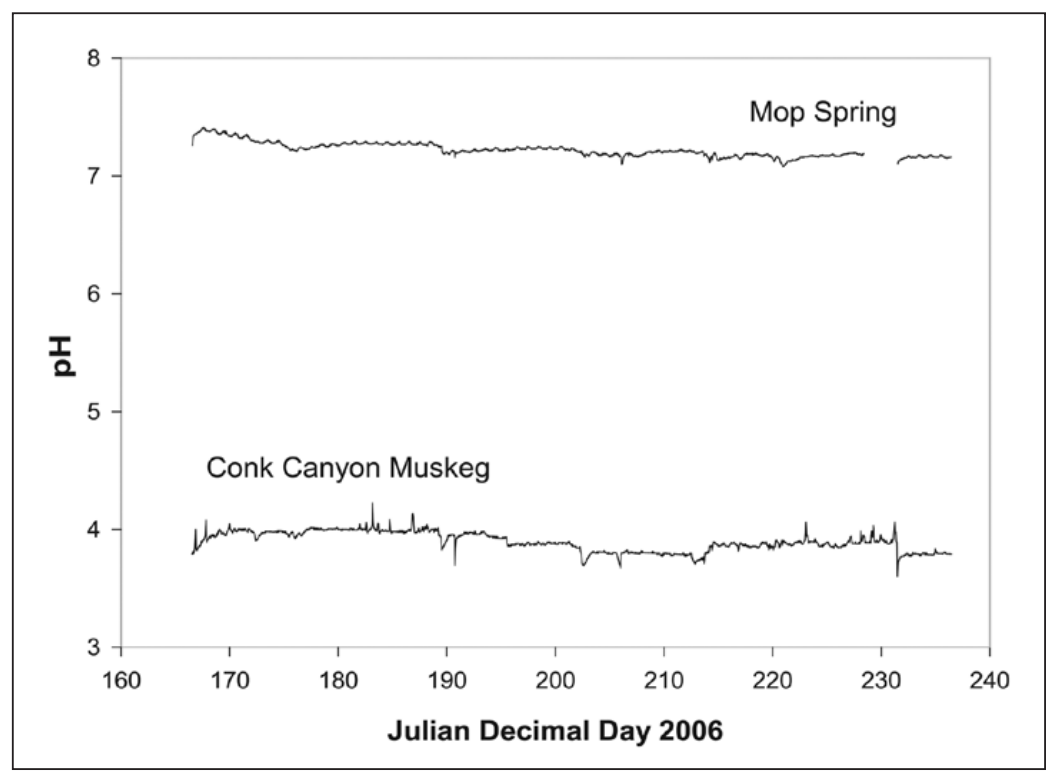

Fig. 4: $p H$ for the insurgence of Conk Canyon and resurgence of Mop Spring.

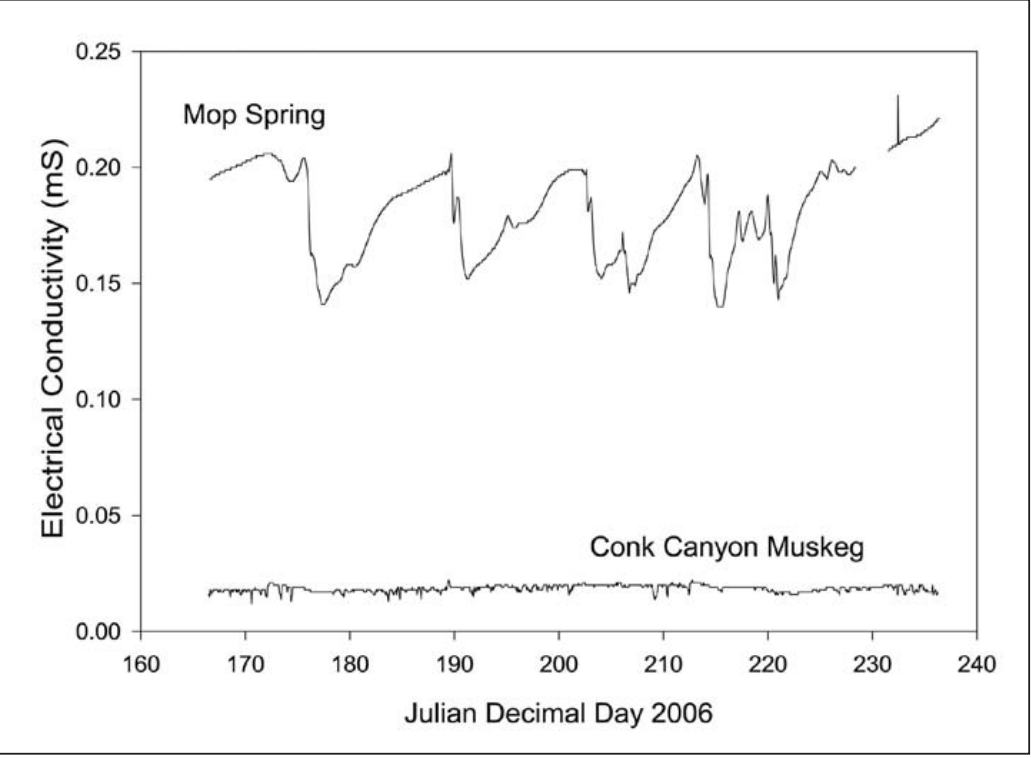

Fig. 5: The specific conductance for both the resurgence and the muskeg site. cipitation, there is an increased amount of water coming through the system as indicated by the stage. During these storm events the water has a greater velocity, so is in contact with the limestone for less time and has had less time to equilibrate to the buffered karst $\mathrm{pH}$. The $\mathrm{pH}$ at the resurgence also shows a diurnal signal in phase with the water temperature. As water temperature increases there is an increased ion activity resulting in a higher $\mathrm{pH}$. This peak corresponds with the air temperature and water temperature being at a maximum in the afternoon.

The $\mathrm{pH}$ buffering from the muskeg waters to the water resurging at the karst spring suggests that the system chemistry is dominated by calcite mineral dissolution. Systems showing similar $\mathrm{pH}$ values of the input waters to karst systems have been recorded in several places in Tennessee (Wicks \& Groves, 1993). These $\mathrm{pH}$ values were created by sulfuric acid mine drainage instead of organic acids. The buffering capacity of the karst system that is observed in acid mine drainage is similar to the buffering capacity on organic acids.

The specific conductance of the Conk Canyon muskeg waters had an average of $0.018 \mathrm{mS}$. Once the water resurges from the karst system, the specific conductance has increased to an average of $0.182 \mathrm{mS}$. The Conk Canyon specific conductance measurement varied from $0.012 \mathrm{mS}$ to $0.021 \mathrm{mS}$, as compared with the range of $0.140 \mathrm{mS}$ to $0.231 \mathrm{mS}$ at Mop Spring (Fig. 5). The increase of the specific conductance from the muskeg to the resurgence indicates there is an increase in ionic strength be-

decrease in $\mathrm{pH}$ is from this increase in water creating an acid pulse by carrying the hydrogen ions down gradient through the muskeg.

Downstream at the resurgence, the $\mathrm{pH}$ shows a more typical value for a karst system with an average of 7.22. During the study period, the $\mathrm{pH}$ ranged from a low of 6.85 to a high of 7.22. The low $\mathrm{pH}$ values were associated with storm events. With the increase in pre- tween insurgence and resurgence. The specific conductance is inversely proportional to the water levels. When there is a lower stage, the velocity of the water is slower therefore allowing the water to be in contact with the limestone longer. This lower amount of water increases the conductivity because of the increased concentration of ions introduced into solution. 


\section{CONCLUSIONS}

The collection and interpretation of water chemistry data from the Conk Canyon - Mop Spring drainage system in the Tongass National Forest displays the buffering capacity of the karst system in the presence of concentrated acid inputs. The insurgence waters at Conk Canyon are draining a muskeg watershed and have low ionic strength, an acidic $\mathrm{pH}$ and fluctuations in water temperature. As these waters travel through the karst system to the resurgence at Mop Spring, they have undergone carbonate chemistry reactions to buffer the $\mathrm{pH}$, dissolve more calcium ions and buffer the temperature before it flows out to the ocean. The buffering process from the carbonate karst system is the agent of evolution from these muskeg waters to waters that can support productive and diverse aquatic communities. Bryant et al. (1998) observed a relationship between alkalinity and coho salmon density on Prince of Wales Island. Streams that show a high alkalinity signature are those associated with karst systems such as Mop Spring. They reported that waters coming from non-karst terrains with muskegs in their watersheds had alkalinities less than half of those of waters from karst systems. These non-karst waters have not undergone the karst buffering processes that are the agent of evolution from muskeg to resurgence spring. The geochemical behaviour of Mop Spring does not differ significantly from karst springs that do not have highly acidic inputs. As such, it appears that the hydrogen from the acidic muskeg waters is rapidly depleted upon entering the karst system and does not propagate down gradient to the resurgence.

This study represents the overall evolution from the insurgence waters that have not yet touched the limestone to the resurgence waters which have been in residence in the karst system. The period of this study was during the summer season. To gain more information about the buffering capacity of the system, continuous data are needed for a whole year or more. This extended time frame would help better understand the evolution from muskeg waters to carbonate waters during all atmospheric conditions. It would also be beneficial to obtain data from several of the different input areas into this karst system. For this study it was assumed the water chemistry of the Conk Canyon muskeg water was representative of other muskeg water draining into the system. To quantify this assumption, different muskeg inputs could be monitored.

\section{ACKNOWLEDGEMENTS}

Support for this research was provided by the Karst Waters Institute, the Graduate School of Western Kentucky University, the Hoffman Environmental Research
Institute, the Tongass National Forest, and the Geological Society of America GeoCorps America Program.

\section{REFERENCES}

Bryant, M.D. \& Swanston, 1998: Coho Salmon Populations in the Karst Landscape of North Prince of Wales Island, Southeast Alaska.- Transactions of the American Fisheries Society, 127, 425-433.

Elliot, W.R., 1994: Alaska's Forested Karstlands.- American Caves, 7, 8-12.

Prussian, K. \& J. Baichtal, 2003: Watershed Delineation on Prince of Wales Island, Southeast Alaska.- US Forest Service, Tongass National Forest, Alaska.
Swanson, D., 1993: Preliminary report on current research into stream productivity of karst versus nonkarst dominated streams. Research Geologist, Forestry Sciences Lab. Juneau AK.

Wicks, C.M., \& C.G. Groves, 1993: Acidic mine drainage in carbonate terrains: geochemical processes and rates of calcite dissolution.- Journal of Hydrology, $146,1-4,13-27$. 